\title{
JSP
}

Journal of Scientific Perspectives

Volume 3, Issue 2, Year 2019, pp. 111-118

E - ISSN: 2587-3008

URL: http://ratingacademy.com.tr/ojs/index.php/jsp

DOI: https://doi.org/10.26900/jsp.3.012

Research Article

\section{DETERMINATION OF SOME MACRO ELEMENT CONCENTRATIONS AND CHLOROPHYLL-A DISTRIBUTION IN A SHALLOW LAKE WETLAND (GÖKÇEADA SALT LAKE LAGOON, ÇANAKKALE/TURKEY)}

\author{
Herdem ASLAN* \& Onur GÖNÜLAL** \\ * Prof.Dr., Çanakkale Onsekiz Mart University, Faculty of Arts and Science, Department of Biology, \\ Çanakkale,TURKEY, E-mail: asherdem@comu.edu.tr \\ ORCID ID: https://orcid.org/0000-0002-0872-2919 \\ **Assoc. Prof. Dr., Istanbul University, Department of Gökçeada Marine Research, Faculty of \\ Fisheries, Istanbul, TURKEY, E-mail: ogonulal@istanbul.edu.tr \\ ORCID ID: https://orcid.org/0000-0002-5559-3953
}

Received: 8 February 2019; Accepted: 2 April 2019

\begin{abstract}
In this study, the macro element concentrations and chlorophyll-a distribution in the Gökçeada Salt Lake Lagoon which is in the category of Shallow Lake Wetland in Gökçeada (Canakkale) were evaluated. For this purpose, some macro elements (Nitrite, Nitrate, Sulfate, Phosphate, Calcium, Magnesium, Potassium, and Phosphorus) and chlorophyll-a levels as well as water temperature and dissolved oxygen values were measured in 2016 as seasonally (January, May, August, November) from three stations. During the autumn season, nitrite, nitrate, phosphate and sulfate values measured as $5.65 \mathrm{ppm} ; 16.9 \mathrm{ppm} ; 77 \mathrm{ppm}$; and $8547 \mathrm{ppm}$, respectively. As a result, the macro element concentrations deposited in the sediment and the chlorophyll-a amounts of the lake was signed to the ecological conditions are very suitable for the development of eutrophication. In the end of the study, some suggestions were done to protect the ecosystem balance.
\end{abstract}

Keywords: Gökçeada, Salt Lagoon, Macro element, eutrophication

\section{INTRODUCTION}

Wetlands encompass many different and productive resources worldwide like supply water and food, flood control, microclimate stabilization, wave breaking, and aquaculture due to their hydrodynamic structure meanwhile ensuring to preserve the biodiversity of the region as well (Ceran, 2006; Erdem, 2013). The ecological balance in wetlands is provided by existing harmony between physicochemical and biological properties with the surrounding environmental conditions, thus these ecosystems maintain their function through protection of this balance (Camur-Elipek, et al., 2017). 
The coastal lagoons, which are considered as wetlands, also exhibit a special hydrological structure by forming a transition zone between fresh and salt water because they are very close to the marine areas and they have perfect hydrodynamic perspective and very sensitive structures (Camur-Elipek and Kirgiz, 2011; Erdem, 2013). However, the pollution, carefree agricultural and tourism activities, which accelerate with the increase in human population, lead to deterioration of natural balance especially in coastal lagoons. Human activities have become a major environmental concern to affect these sensitive areas (ÇamurElipek and Kirgiz, 2011). This problem may lead to a change in the dynamics of living organisms in the wetland and may cause the deterioration of the entire ecosystem and the food chain (Çamur-Elipek, et. al., 2010).

High concentrations of nitrogen and phosphorus elements play an important role in the pollution caused by nutrients in aquatic ecosystems (Alkan et al., 2013). These elements, which are necessary for the biochemical cycle, are usually incorporated into the water by anthropogenic activities and their excessive amounts lead to eutrophication which causes serious environmental problems in the aquatic ecosystem (Luo et al., 2011; Alkan et al., 2013). Eutrophication is the major factor on oxygen deficiency due to algal explosion, fish deaths and biodiversity decline (Alkan et al., 2013).

The importance of coastal lagoons in terms of ecological equilibrium with rich biodiversity structure has started to attract attention in Turkey (Dugan, 1991; Sivac1 et al., 2008; Demir, 2008; Turan, 2001). However, each wetland ecosystem has its own physicochemical and biological properties due to autochtonic and allochonic factors like as climatic and topographic conditions of the its geography. Therefore, each wetland ecosystem should be evaluated separately.

The effects of environmental factors on wetlands can lead to changes in some physicochemical properties in the water and due to these changes; it reached a visible level of ecosystem degradation. Increased water temperature, especially due to global climate change and low water level, may have an effect on dissolved oxygen values, while an increase in chlorophyll- $a$ amounts may lead to a decrease in light permeability in water and thus decrease in oxygen produced by photosynthesis (Kökmen et. al., 2007; Arslan et al., 2018a). Decreased oxygen content may prevent the bacteria that decompose organic matter in the sediment and restore the ecosystem. Another factor that may lead to a similar situation can be found in the increase of excess phytoplankton due to the accumulation of macro and microelements in water, especially due to anthropogenic factors, therefore it would cause eutrophication in the shallow lake wetlands (Çamur-Elipek, et. al., 2010).

Some substances (nitrogen $(\mathrm{N})$, phosphorus $(\mathrm{P})$, potassium $(\mathrm{K})$, calcium $(\mathrm{Ca})$, magnesium $(\mathrm{Mg})$, sulfur $(\mathrm{S})$ and their derivatives (such as ammonium $\left(\mathrm{NH}_{4}\right)$, nitrite $\left(\mathrm{NO}_{2}\right)$, nitrate $\left(\mathrm{NO}_{3}\right)$, sulfate $\left(\mathrm{SO}_{4}\right)$ and phosphate $\left.\left(\mathrm{PO}_{4}\right)\right)$ which are called macro elements are introduced into aquatic ecosystems in many ways, thus they can lead to excessive increasing of phytoplankton.

Previously, in the report published by the Ministry of Forestry and Water Affairs in 2012, analyses of the physical and biological data, and water quality as well as the socioeconomic evaluation of Gökçeada Salt Lake Lagoon was conducted (Anonymous, 2012). Also, Bassler-Veit et al. (2013) measured some of the environmental variables (temperature, $\mathrm{pH}$ and salinity) in the lake. However, the concentrations of macro elements in the wetland and their possible effects on the ecosystem have not been evaluated yet.

The purpose of this study, some macro element concentrations (Nitrite nitrogen, Nitrate nitrogen, Sulfate, Phosphate, Calcium, Magnesium, Potassium, and Sulfur) and chlorophyll$a$,dissolved oxygen and water temperature analyses were carried out in Gökçeada Salt Lake 
Lagoon, which is in the status of National Impact Status. The current levels belong to the nutrients and chlorophyll- $a$ of the wetland area and the eutrophication situation that may occur in the area were examined and suggestions were made in terms of sustainable use in the wetland.

\section{MATERIAL AND METHODS}

Gökçeada Island (in Canakkale) which is the largest island in Turkey, located in the North of the Aegean Sea. Salt Lake Lagoon, located in the south-east of the island, is a coastal lagoon with a maximum depth of 2 meters in an area of approximately $2 \mathrm{~km} 2$ (Fig. 1). The National Wetland Committee (NWC) declared Gökçeada Salt Lake as "Wetland of National Importance" in December 2018. Although Gökçeada Salt Lake hosts many species, especially the Flamingo population, the lake is exposed on tourism activities and the effects of the surrounding areas especially in the summer months (Aslan et al., 2018).

In this study, some macro element concentrations, chlorophyll- $a$, water temperature and dissolved oxygen levels were investigated in Gökçeada Salt Lake Lagoon. While sampling was made for some variables (Calcium, Magnesium, Potassium, Phosphorus, water temperature, dissolved oxygen and chlorophyll- $a$ levels) in 2016 from 3 stations selected from the lake, at the January, May, August and November, the other parameters (Nitrite $\left(\mathrm{NO}_{2}{ }^{-} \mathrm{N}\right)$, Nitrate $\left(\mathrm{NO}_{3}{ }^{-}\right.$ $\mathrm{N})$, Sulfate $\left(\mathrm{SO}_{4}^{-}\right)$and Phosphate $\left(\mathrm{PO}_{4}^{-3}\right)$ values) could be measured in a single season at the sampling stations (Fig. 1).

Fig. 1. Location of Gökçeada Salt Lake Lagoon and Sampling Stations (adapted from Google.Earth)

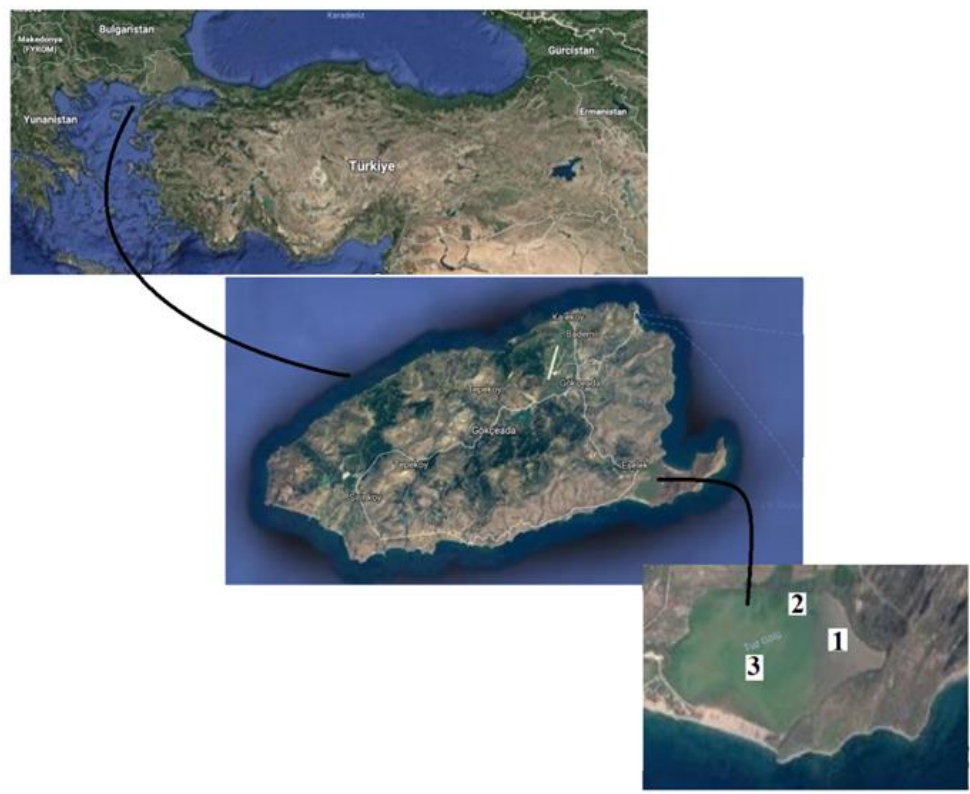

For this purpose, water temperature $\left({ }^{0} \mathrm{C}\right)$ and dissolved oxygen $(\mathrm{mg} / \mathrm{L})$ values were measured with the YSI556 model multiprobe system device during field studies. Water samples were taken by Ruttner water sampler device and sediment samples were taken by Ekman grab $\left(15 \times 15 \mathrm{~cm}^{2}\right)$ and the materials were transferred to the laboratories in ÇOBILTUM (Çanakkale Onsekiz Mart University, Science and Technology Research Center) and TUTAGEM (Trakya University, Tecnhnology and Research Center) to analyze macro-element concentrations (Nitrite, Nitrate, Phosphate, Sulfate, Calcium, Magnesium, Sulfur, Potassium). The macro element analyses were made by Ion Chromatography device (IC-MS: Metrohm Ion Chromatography System) and Inductively Paired Plasma Mass Spectrometer device (ICP-MS: Agilent Technologies 7700 XX ICP-MS System) and using EPA 200.8 method (EPA, 1994; Uçar, 2011). The analysis was performed in three replicates for each sample and the mean 
values of the results calculated according to the calibration curve were taken. In addition, chlorophyll- $a$ determinations were carried out using classical spectrophotometric methods (Egemen ve Sunlu, 1999).

\section{RESULTS AND DISCUSSION}

As a result of the analyzes performed in the samples taken from the stations in the Gökçeada Salt Lake Lagoon, the magnesium ratios ranged from $373 \mathrm{ppm}$ to $5998 \mathrm{ppm}$ and had an average value of $3048 \mathrm{ppm}$; calcium levels vary between $749 \mathrm{ppm}$ and $18740 \mathrm{ppm}$ and have an average of $9489 \mathrm{ppm}$; the amount of potassium is between $204 \mathrm{ppm}$ and $4508 \mathrm{ppm}$ and has an average value of $1527 \mathrm{ppm}$; Phosphorus levels were found to be between $172 \mathrm{ppm}$ and 783 ppm and had an average of 366 ppm (Fig. 2). During the autumn season when the agricultural fertilization periods ended, nitrite, nitrate, phosphate and sulfate values measured as $5.65 \mathrm{ppm}$; $16.9 \mathrm{ppm} ; 77 \mathrm{ppm}$; and $8547 \mathrm{ppm}$, respectively (Fig. 2). Especially the phosphorus and Nitrogen-N concentrations in the sediment directly affect the quality of water (Perak et al., 2016). Thus, nutrients will lead increasing the primer productivity in an aquatic ecosystem, relatively. The chlorophyll-aconcentrations which increasing by the macro elements may indicate the environmental conditions are suitable for eutrophication development in the ecosystem.

Fig. 2. Macroelement Concentrations Measured in Gökçeada Salt lake Lagoon (ppm)

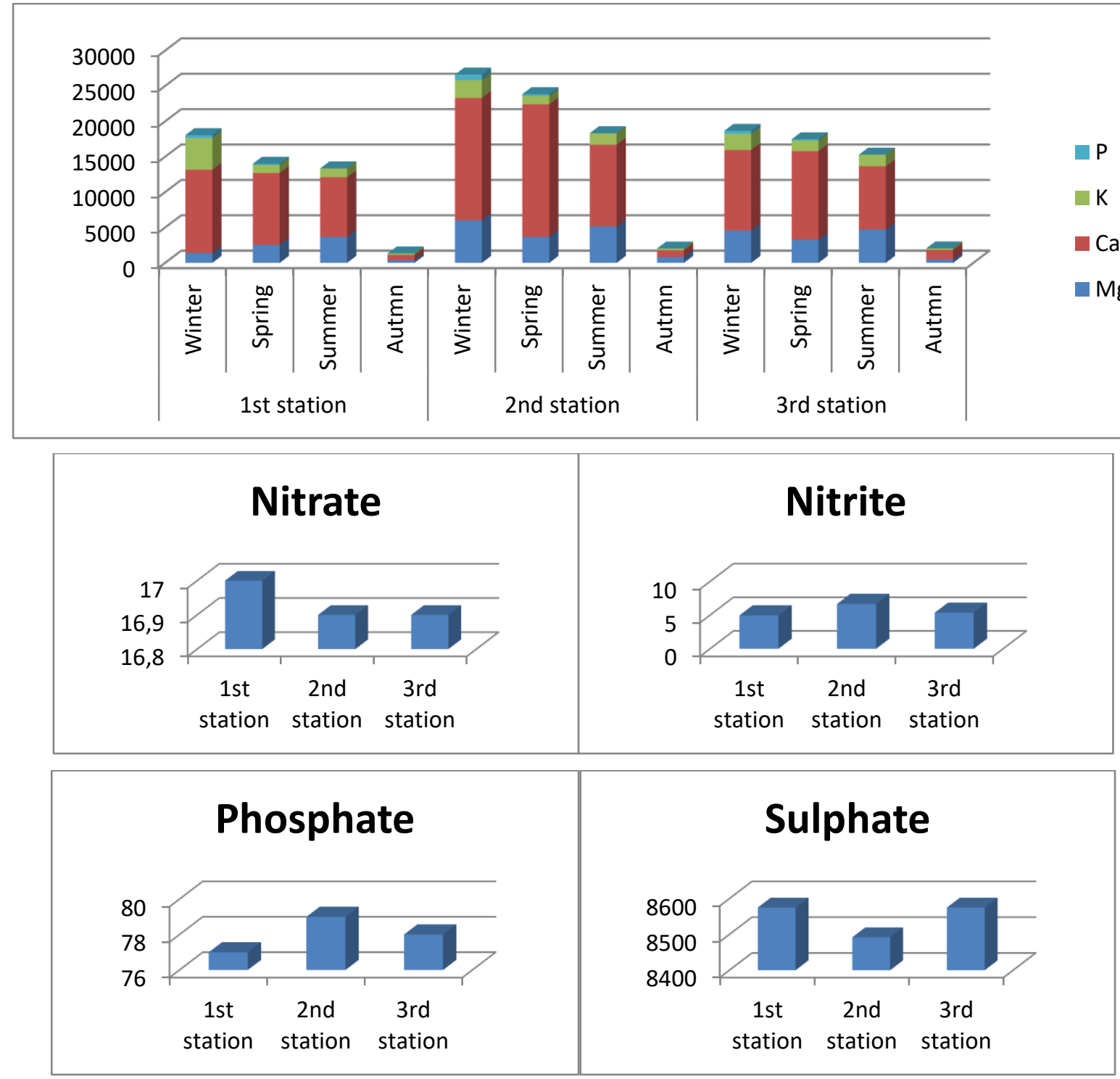


Although macro elements are very important for primer productivity and other organisms in water, they may bioaccumulated by the food web and they may turn into toxic substances. Nitrogen, vital for the metabolic functions of photosynthetic organisms, is an important macro element in the formation of proteins, hormones, chlorophyll, vitamins and enzymes in living organisms. Although the process of demineralization in ecosystems is the main natural source of nitrogen, it is highly effective in transporting nitrogen to aquatic ecosystems in agricultural activities. Photosynthetic organisms may take the nitrogen transported to the aquatic ecosystem with superficial flow waters in the form of Nitrate nitrogen $\left(\mathrm{NO}_{3}{ }^{-} \mathrm{N}\right)$ and Ammonium nitrogen $\left(\mathrm{NH}_{4}{ }^{+} \mathrm{N}\right)$ (Chapman and Reis 1999). However, most of the aquatic photosynthetic organisms cannot readily use ammonium nitrogen and can be used after nitrification by converting the nitrate into nitrogen form.

Phosphorus is one of the most basic macro elements necessary for metabolic activities of photosynthetic organisms. Phosphorus and its derivatives, which can enter into aquatic ecosystems, especially in agricultural activities in different ways (such as the use of detergents), act as a catalyst that initiates metabolic reactions in photosynthetic organisms and also encourages the use of nitrogen in the use of nitrogen.

The presence of high levels of macro elements (especially Nitrogen and its derivatives) in aquatic ecosystems leads to an increase in primary productivity. This is the first step the process (called eutrophication) of changing the physical, physiological and biological characteristics of water and the change in the ecosystem structure is inevitable. Phosphate is also an important eutrophication compound and may lead to phytoplankton growth and an increase in chlorophyll-a ratio. Especially high nitrite concentrations and agricultural activities are important factors limiting the life of aquatic organisms (Kökmen et al., 2007; Çamur-Elipek, et al., 2010). In addition, high amounts of nutrients in water are reported to have negative effects on organ development of organisms (Arslan et al., 2018b).

In this study, chlorophyll- $a$ amounts were found to vary between $0.56 \mathrm{ppm}$ and 14.56 ppm and have an average of $4.01 \mathrm{ppm}$ (Fig. 3). The chlorophyll values that begin to rise in the winter reaches the highest value in the spring. The determined chlorophyll- $a$ values were observed to exceed the recommended eutrophication limit value $(0.008 \mathrm{ppm})$ for the natural conservation area (Anonymous, 2004).

Fig. 3. Seasonal Distribution of Chlorophyll- $a$ Concentrations in Gökçeada Salt Lake Lagoon (ppm)

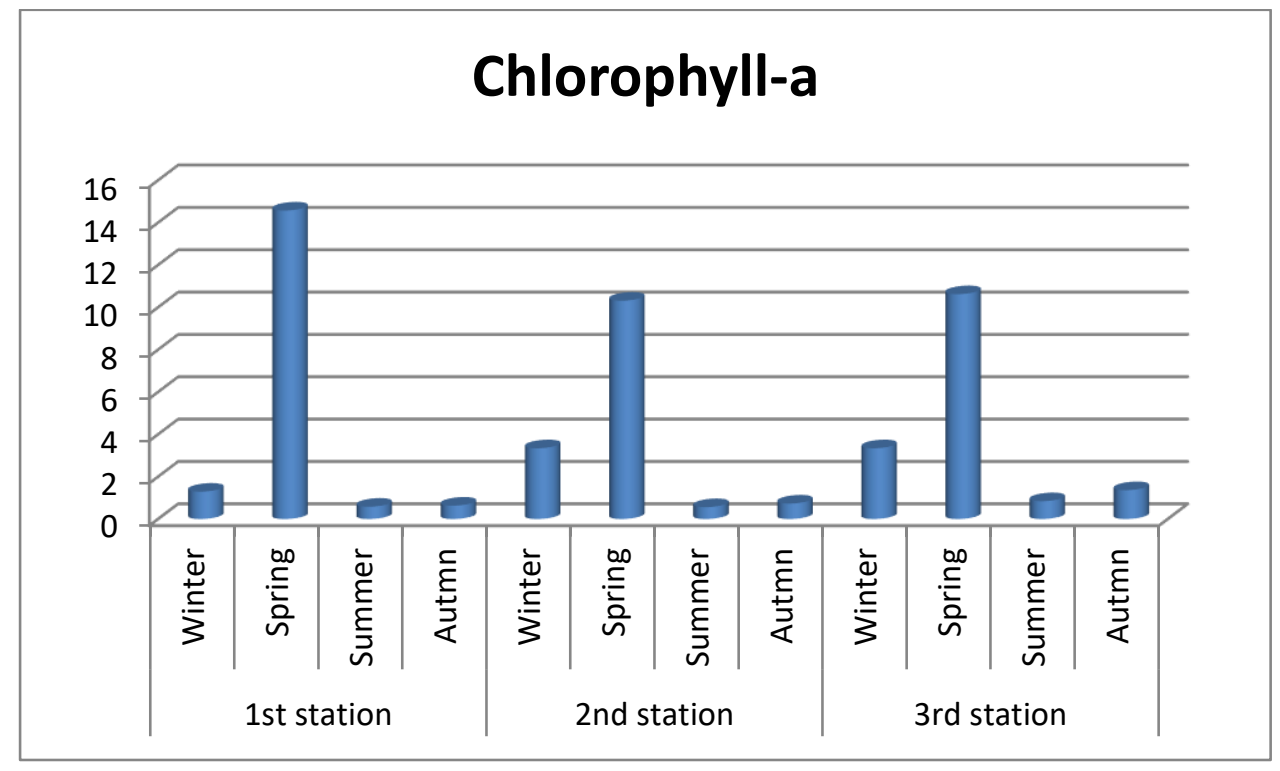


Dissolved oxygen and water temperature values were observed to be inversely related to each other as indicated in the literature (Fig. 4). Since the amount of dissolved oxygen affects the self-cleaning capacity of water, the low concentration, especially in the spring period, triggers eutrophication (Tokatlı et al., 2014; Çiçek et al., 2017). In particular, it is thought that increased primary productivity factors due to temperature increase may cause high chlorophyll$a$ amounts in spring season.

Fig. 4. Comparison of Seasonal Variation of Temperature and Dissolved Oxygen in Gökçeada Salt Lake Lagoon

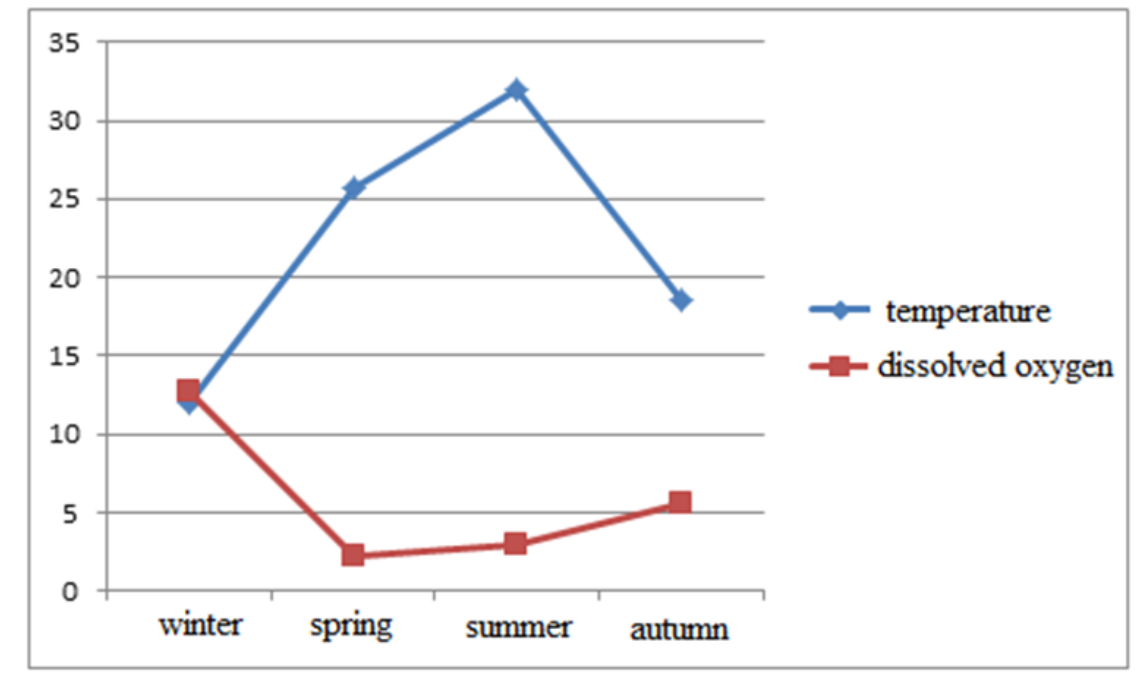

As a result, it has been determined that Gökçeada Salt Lake Lagoon, which is in the protection status for biological diversity, has a high Chlorophyll- $a$ concentration during the spring season and it is thought to have developed as a result of the increase in primary productivity. This situation indicates that this area, which hosts many living things and is used for recreational purposes, is about to lose its ecological balance due to eutrophication. In order to prevent this situation, it is necessary to determine the pollutant loads that have a negative impact on the lake and to take necessary measures, and to monitor the water quality of the lake by eliminating the wastes from the settlement area or agricultural wastes. Further investigation should be devoted to monitoring of species and their relationships, in order to predict impact of natural or human induced stress conditions.

\section{Acknowledgements}

This study was supported by ÇOMÜ-BAP project (FHD-2016-882) and some results were obtained from the report of TÜBİTAK project (115Y457). 


\section{LITERATURES}

ALKAN, A., SERDAR, S., FİDAN, D., AKBAŞ, U., ZENGİN, B., KILIÇ, M. B., 2013, Physico-Chemical Characteristics and Nutrient Levels of the Eastern Black Sea Rivers, Turkish Journal of Fisheries and Aquatic Sciences, 13: 847-859

ANONYMOUS, 2004, Su Kirliliği Kontrol Yönetmeliği (SKKY), Resmi Gazete Tarihi: 31.12.2004 Resmi Gazete Say1s1: 25687.

ANONYMOUS, 2012, Gökçeada Lagünü Sulak Alan Alt Havzası Biyolojik Çeşitlilik Araştırması, T.C. Orman ve Su İşleri Bakanlığı Doğa Koruma ve Milli Parklar Genel Müdürlüğü Hassas Alanlar Dairesi Başkanlığı.

ARSLAN, N., ULUKÜTÜK, S., MERCAN, D., 2018a, Assessment of water quality in three sub-basins of Susurluk River (Northwest Anatolia) according to invertebrates and biotic indices, Biological Diversity and Conservation, 11(3): 1-8.

ARSLAN, N., MERCAN, D., AKKAN KÖKÇÜ, C., ARSLAN, T., 2018b, Antenna and mouthpart defect in Chironomus (Camptochironomus) tentans larvae (Chironomidae) and their relevance with habitat characteristics, Biological Diversity and Conservation, 11(3): 180-189.

ASLAN, H., GÖNÜLAL, O., CAN YİLMAZ, E., ÇAMUR ELIPEK, B., BAYTUT, Ö., TOSUNOĞLU, M., KARABACAK, E., KURT, Y., 2018, Species diversity in lentic, lotic, marine and terrestrial biotopes of Gökçeada Salt Lake Wetland (Çanakkale, Turkey). Fresenius Environmental Bulletin, 27:2853-2867

BASSLER-VEIT, B., BARUT, İ.F., MERİÇ, E., AVŞAR, N., NAZİK, A., KAPANYEŞILYURT, S., YILDIZ, A., 2013, Distribution of microclima, meifauna and macrofauna assemblages in the hypersaline environment of Northeastern Aegean Sea coast, Journal of coastal Research, 29 (4): 883-898.

CERAN, Y, 2006, Sulak Alanların Akılcı Kullanımı, Çevre ve İnsan Dergisi, Sayı:66, Çevre ve Orman Bakanlığ Yayını, pp 16-20.

CHAPMAN, J. L., REİS, M. J., 1999, Ecology, principles and applications, Cambridge University Pres, $330 \mathrm{p}$.

ÇAMUR-ELIPEK, B., ARSLAN, N., KIRGIZ, T., ÖTERLER, B., GÜHER, H., ÖZKAN, N. 2010. Analysis of Benthic Macroinvertebrates in Relation to Environmental Variables of Lake Gala (Edirne/Turkey), Turkish Journal of Fisheries and Aquatic Sciences, 10(2): 235-243

ÇAMUR-ELIPEK, B., KIRGIZ, T., 2011. The Evalution of Some Limnological Features of the Lagoon Lakes in European Part of Turkey, edited by Frank Columbus in the book "Lagoons: Biology, Management and Environmental Impact." at Nova Science Publishers, Inc. 400 Oser Avenue, Suite 1600 Hauppauge, NY 11788, USA.

ÇAMUR-ELIPEK, B., GÜHER, H., OTERLER, B., TAS-DIVRİK, M., ALTINOLUKMIMIROĞLU, P., 2017. Determining of Water Quality by Using Multivariate Analysis Techniques In A Drinking/Using Water Reservoir In Turkey, Fresenius Environmental Bulletin 26(8): 5007-5017.

ÇİÇEK, A., UYSAL, E., KÖSE, E., TOKATLI, C., 2017, Eskişehir'de Yer Alan Bazı Sulama Göletlerinin Su Kalitesinin Değerlendirilmesi, Nevşehir Bilim ve Teknoloji Dergisi Cilt 6 (ICOCEE 2017 Özel Sayı) 440-446. 
DEMIR, A., 2008, Akyatan Lagününde Tuzluluk ve Bazı Kirlilik Düzeylerinin Saptanarak Coğrafi Bilgi Sistemi Destekli Dağılımlarının Belirlenmesi (Yüksek Lisans Tezi). Çukurova Üniversitesi Fen Bilimleri Enstitüsü, Citing Internet Sources: https://tez.yok.gov.tr/UlusalTezMerkezi/

DUGAN, P. J., 1991, Wetlands, regional planning and the developmentf assistance community, Landscape and Urban Planning, 20(1): 211-214.

EGEMEN, Ö., SUNLU, U., 1999. Su Kalitesi, Ege Üniversitesi yayınları

EPA 1994, Creed, J. T., Brockhoff, C. A., Martin, T. D. Method 2008, Determination of Trace Elements in Waters and Wastes by Inductively Coupled Plasma - Mass Spectrometry, Revision 5.4; Environmental Monitoring Systems Laboratory Office of Research and Development, U.S. Environmental Protection Agency, Cincinnati, Ohio. Citing Internet Sources: $\quad$ https://www.epa.gov/homeland-security-research/epa-method-2008determination-trace-elements-waters-and-wastes

ERDEM, O., 2013, Sulak alanların işlev ve değerleri. Bölüm 2, Sulak alanlar (eds. Dr. B. T. Meriç, S. Çağırankaya), Orman ve Su İşleri Bakanlığı, Doğa Koruma ve Milli Parklar Genel Müdürlüğü,

GÜLER, Ç., 1997, Su Kalitesi. Çevre Sağlı̆̆1 Kaynak Dizisi, 43, s. 95. Citing Internet Sources: https://sbu.saglik.gov.tr/Ekutuphane/kitaplar/css43.pdf

LUO, G., BU, F., XU, X., CAO, J., SHU, W, 2011, Seasonal variations of dissolved inorganic nutrients transported to the linjiang bay of the three gorges reservoir, China. Environmental Monitoring and Assessment, 173: 55- 64

KÖKMEN, S., ARSLAN, N., FILIK, C., YILMAZ, V., 2007, Zoobenthos of Lake Uluabat, a Ramsar Site in Turkey, and Their Relationship with Environmental Variables, Clean 35 (3): $266-274$.

UÇAR, B., 2011, İyon Kromatografi Kullanarak Çeşitli Örneklerde Perklorat Analizi (Musluk Suyu, Havuz Suyu, Yüzey Suyu, Süt) (Yüksek Lisans Tezi). İstanbul Teknik Üniversitesi Citing Internet Sources: https://tez.yok.gov.tr/UlusalTezMerkezi/

PERAK, S. H., TALİB, A., YUSOFF, M. A., HASAN, Z. A., ISMAIL, W. R., ABUSTAN, M. S., 2016, Nutrient Concentration Distribution in Sediment and Overlying Water at Bukit Merah Reservoir, MATEC Web of Conferences, 47, 005004.

SIVACI, E.R., YARDIM, Ö., GÖNÜLOL, A., BAT, L., GÜMÜŞ, F. 2008. Sarıum (SinopTürkiye) Lagününün Bentik Algleri, J. of Fisheries Sciences, 2(4): 592-600.

TOKATLI, C., KÖSE, E., ÇİÇEK, A., 2014, Assessment of the Effects of Large Borate Deposits on Surface Water Quality by Multi Statistical Approaches: A Case Study of the Seydisuyu Stream (Turkey), Polish Journal of Environmental Studies, 23 (5): 17411751.

TURAN, L., 2001, Türkiye'nin Ornitolojik Konumu ve Sulak Alanlar, Hacettepe Üniversitesi Eğitim Fakültesi, 72-178. 